\title{
Analysis of the Irtysh surface water as natural sources of water supply and steam production in the heat and power industry
}

\author{
Galina I. Egorova ${ }^{1}$, Andrey N. Egorov ${ }^{1}$, Yuriy V. Kobenko ${ }^{2,}{ }^{*}$, Tatiana A. Martseva ${ }^{2}$, and \\ Elena $\mathrm{S}$. Riabova ${ }^{3}$ \\ ${ }^{1}$ Tyumen Industrial University, 626150 Tobolsk, Russia \\ ${ }^{2}$ National Research Tomsk Polytechnic University, 634050 Tomsk, Russia \\ ${ }^{3}$ Samara University, 443086 Samara, Russia
}

\begin{abstract}
The article demonstrates the results of experimental analysis of the Irtysh and Tobol underground and surface water as natural water supply sources and steam production in the heat and power industry; priority locations for water sampling have been identified and substantiated; a qualitative analysis of the Irtysh and Tobol samples has been proved; the reasons for the deviation from the water quality and the required degree of treatment for bringing it to the required indicies are revealed; the mineral composition of water is determined taking into account the peculiarities of the hydrological layers through which the river flows; it is proved that the organic composition is formed due to compounds that are washed out of the reservoir's soil as a result of biological processes; the mineral and organic substances that are brought into the Irtysh, Tobol by waste waters of populated areas and industrial enterprises are revealed; it is proved that the water of the Irtysh River is fresh, belongs to hydrocarbonate class and is suitable for steam production in the heat and power industry.
\end{abstract}

\section{Introduction}

The aim of the research is to conduct a quantitative and qualitative analysis of underground and surface water samples of the Irtysh and Tobol river as natural sources of water supply and steam production in the heat and power industry. The methods of the research are chemical and microbiological analysis.

Nowadays water purification is the most important task of water treatment engineers at thermal power plants. For long-term and trouble-free operation of thermal and power equipment, it is necessary to purify water from suspended solids and aggressive factors that cause metal corrosion. In order to complete this task heat power companies have a chemical water treatment section, the equipment of which depends on the source water quality and the purpose of purified water consumption [1].

\footnotetext{
*Corresponding author: serpentis@list.ru
} 
Tobolsk CHP was designed and built to meet the needs of the Tobolsk industrial site in the live steam and electric power, and also to provide the city of Tobolsk with thermal energy [3].

In the heat power industry the raw material for steam production and the coolant is water. After proper processing, it is used for the following purposes: a) as a source material for steam production in boilers, steam generators, boiling water reactors, evaporators, steam converters; b) for the condensation of spent vapor in steam turbines; c) in order to cool various items and systems at TPP and NPS; d) as a coolant in the primary circuit of NPS and WWER, in heat networks and hot water systems. Unique properties and water indices are known $\left(T_{\mathrm{cr}}=100.0^{\circ} \mathrm{C}, T_{\mathrm{m}}=0.0^{\circ} \mathrm{C}, T_{\mathrm{b}}=374.12^{\circ} \mathrm{C}, p_{\mathrm{cr}}=221.2\right.$ bar, $\left.q_{\mathrm{cr}}=317.8 \mathrm{~kg} / \mathrm{m}^{3}\right)$. In comparison with all the liquid and solid bodies, water has the greatest heat capacity. Having heated up during the summer period, the water cools down in winter, rejecting the heat to the atmosphere. Water has the greatest surface tension in comparison with all known liquids, with the exception of mercury, which is of great importance for the life of the plant world. Water surface tension and density determine the height at which it can rise in the capillary systems. This property provides the water rise in plant stems and tree trunks $[4,5]$.

It is important to highlight that one of the most important physicochemical properties of water is its ability to form solutions. Water is the best solvent, incomparable with any other liquid, it dissolves solid compounds, liquids and gases. Water is a reactive substance. Oxides of many metals and metalloids combine with water, forming bases and acids; a large number of salts form crystalline hydrates with water; the active metals react with water to liberate hydrogen. When water interacts with salts of weak acids or weak bases, hydrolysis of these salts takes place, that is, there is an interaction of salt ions with water ions [6].

The listed water characteristics and, first of all, its exclusive ability to dissolve various substances have caused the presence of several natural waters on the Earth, which often stand in marked contrast with each other in their qualitative characteristics. We have developed a program for monitoring the quality of underground and natural water of the river Irtysh, Tobol. Priority sampling points in the area of Tobolsk city and its district are the following: the ferry opposite the village of Bekerevo, village Abalak, settlement Sumkino. The periodicity of analyses was carried out on a quarterly basis [7]. The analysis of the samples quality was carried out according to the current strategies and methods of analysis (SanPiN 2.1.4.1074-01 "Hygienic requirements for water quality of centralized drinking water supply systems, GN 2.1.5.1315-03 "Maximum permissible concentration of chemicals", etc.). The qualitative characteristics of the water samples of the Irtysh and Tobol river were also compared with GOST (All-Union State Standard) 2761-84. The composition of surface water sources met the following requirements:

1) dry residue not more than $1000 \mathrm{mg} / \mathrm{dm}^{3}$ (according to the sanitary-epidemiological service it is allowed up to $1500 \mathrm{mg} / \mathrm{dm}^{3}$ );

2) the concentration of chlorides and sulfates is not more than 350 and $500 \mathrm{mg} / \mathrm{dm}^{3}$, respectively, the total hardness is not more than $7 \mathrm{mmol} / \mathrm{m}^{3}$ (according to the sanitaryepidemiological service it is allowed up to $10 \mathrm{mmol} / \mathrm{m}^{3}$ ),

3) concentration of chemicals (Table 1) should not exceed the maximum allowable concentration for household, cultural and social water use, as well as radiation safety standards approved by the Ministry of Health.

Table 1. Quality indicators of underground water supply sources according to GOST (classes).

\begin{tabular}{|l|c|c|c|}
\hline Indicators & 1 & 2 & 3 \\
\hline Turbidity, $\mathrm{mg} / \mathrm{dm}^{3}$, not more than & 1.5 & 1.5 & 10.0 \\
\hline Colour, degree, not more than & 20 & 20 & 50 \\
\hline Hydrogen index $(\mathrm{pH})$ & $6-9$ & $6-9$ & $6-9$ \\
\hline Iron, $(\mathrm{Fe}), \mathrm{mg} / \mathrm{dm}^{3}$, not more than & 0.3 & 10 & 20 \\
\hline
\end{tabular}




\begin{tabular}{|l|c|c|c|}
\hline $\begin{array}{l}\text { Manganese }(\mathrm{Mn}), \mathrm{mg} / \mathrm{dm}^{3}, \text { not more } \\
\text { than }\end{array}$ & 0.1 & 1 & 2 \\
\hline $\begin{array}{l}\text { Hydrogen sulphide }\left(\mathrm{H}_{2} \mathrm{~S}\right), \mathrm{mg} / \mathrm{dm}, \\
\text { not more than }\end{array}$ & Absence & 3 & 10 \\
\hline Fluorine $(\mathrm{F}), \mathrm{mg} / \mathrm{dm}^{3}$, not more than & $1.5-0.7$ & $1.5-0.7$ & 5 \\
\hline $\begin{array}{l}\text { Permanganate oxidizability, } \\
\mathrm{mgO} / \mathrm{dm}^{3}, \text { not more than }\end{array}$ & 2 & 5 & 15 \\
\hline $\begin{array}{l}\text { The number of coliform bacteria } \\
(\mathrm{CGB}), \text { in } 1 \mathrm{dm}^{3}, \text { not more than }\end{array}$ & 3 & 100 & 1000 \\
\hline
\end{tabular}

\section{The results of experimental analysis}

The qualitative analysis of the Irtysh and Tobol samples allowed us to divide them into three classes according to the composition of the samples, to identify the reasons for the deviation from the water quality and the required degree of processing in order to bring it to GOST indices that are suitable as water supply sources.

Table 2. Underground water quality indicators of water supply sources Bekerevo village, Abalak village, Sumkino settlement.

\begin{tabular}{|l|c|c|c|}
\hline \multicolumn{1}{|c|}{ Quality indicators } & $\begin{array}{c}\text { Bekerevo } \\
\text { village }\end{array}$ & $\begin{array}{c}\text { Abalak } \\
\text { village }\end{array}$ & $\begin{array}{c}\text { Sumkino } \\
\text { settlement }\end{array}$ \\
\hline Turbidity, $\mathrm{mg} / \mathrm{dm}^{3}$, not more than & 1.5 & 1.5 & 10.0 \\
\hline Colour, degree, not more than & 20 & 20 & 47 \\
\hline Hydrogen index (pH) & 7.1 & 6.9 & 6.8 \\
\hline Iron, $(\mathrm{Fe}), \mathrm{mg} / \mathrm{dm}^{3}$, not more than & 5 & 10 & 20 \\
\hline $\begin{array}{l}\text { Manganese }(\mathrm{Mn}), \mathrm{mg} / \mathrm{dm}^{3}, \text { not more } \\
\text { than }\end{array}$ & 1 & 0.2 & 1.5 \\
\hline $\begin{array}{l}\text { Hydrogen sulphide }\left(\mathrm{H}_{2} \mathrm{~S}\right), \mathrm{mg} / \mathrm{dm}, \mathrm{not} \\
\text { more than }\end{array}$ & 2 & 0.2 & 10 \\
\hline Fluorine $(\mathrm{F}), \mathrm{mg} / \mathrm{dm}^{3}$, not more than & $1.5-0.7$ & 0.7 & 1.5 \\
\hline $\begin{array}{l}\text { Permanganate oxidizability, } \mathrm{mgO} / \mathrm{dm}^{3}, \\
\text { not more than }\end{array}$ & 3 & 2 & 8 \\
\hline $\begin{array}{l}\text { The number of coliform bacteria }(\mathrm{CGB}), \\
\text { in } 1 \mathrm{dm}^{3}, \text { not more than }\end{array}$ & 100 & 8 & 400 \\
\hline
\end{tabular}

The quality indicators of surface water sources - water supply sources of CHP in the districts of villages: Bekerevo, Abalak, Sumkino, were studied on a quarterly basis (table 2).

Table 3. Indicators of surface water sources quality in the village of Bekerevo, village Abalak, settlement Sumkino.

\begin{tabular}{|l|l|l|l|}
\hline & $\begin{array}{l}\text { Bekerevo } \\
\text { village }\end{array}$ & Abalak village & $\begin{array}{l}\text { Sumkino } \\
\text { settlement }\end{array}$ \\
\hline Turbidity, $\mathrm{mg} / \mathrm{dm}^{3}$, not more than & 1400 & 1500 & 10000 \\
\hline Colour, degree, not more than & 35 & 120 & 200 \\
\hline Odour at 20 and $60^{\circ} \mathrm{C}$, points, not more than & 2 & 3 & 4 \\
\hline Hydrogen index $(\mathrm{pH})$ & 6.9 & 6.8 & 7.5 \\
\hline Iron, $(\mathrm{Fe}), \mathrm{mg} / \mathrm{dm}^{3}$, not more than & 1 & 2.5 & 3.5 \\
\hline Manganese $(\mathrm{Mn}), \mathrm{mg}^{-\mathrm{dm}^{3}, \text { not more than }}$ & 0.1 & 1.0 & 1.5 \\
\hline Phytoplankton, $\mathrm{mg} / \mathrm{dm}^{3}$, not more than & 1 & 5 & 8 \\
\hline $\begin{array}{l}\text { Permanganate oxidizability, mgO/dm } \\
\text { more than }\end{array}$ & 13 & 15 & 18 \\
\hline Ultimate BOD, $\mathrm{mgO}_{2} / \mathrm{dm}^{3}$, not more than & 3 & 3.5 & 3.8 \\
\hline $\begin{array}{l}\text { The number of lactose-positive E. coli in } 1 \\
\mathrm{dm}^{3} \text { of water, not more than }\end{array}$ & 1000 & 10000 & 20000 \\
\hline
\end{tabular}


The results analysis of the research of the water taken from the surface of the Irtysh, Tobol river shows the concentration excess of total iron, manganese, high oxidation in the water compared with the maximum permissible concentration that is several times higher in the Sumkino area. The hydrogen index is within the maximum permissible concentration. Moreover, the analysis of surface water for the content of ions was carried out. The content of sodium ions, ion sulfate, ion nitrate, ion silicate $\left(\mathrm{mg} / \mathrm{dm}^{3}\right)$, as shown by the analysis, is contained in all surface and underground water at the indicated locations of the samples (Table 4).

Table 4. Water quality of a surface source (the Irtysh River).

\begin{tabular}{|c|c|c|c|c|c|c|c|c|c|}
\hline \multirow{2}{*}{$\begin{array}{l}\text { Sampling } \\
\text { place }\end{array}$} & \multirow{2}{*}{$\begin{array}{l}\mathrm{PM}, \\
\mathrm{mg} / \mathrm{dm}\end{array}$} & \multicolumn{5}{|c|}{ Content of ions, $\mathrm{mg} / \mathrm{dm}^{3}$} & \multirow{2}{*}{$\begin{array}{l}\text { Solid } \\
\text { residue, } \\
\mathrm{mg} / \mathrm{dm}^{3}\end{array}$} & \multirow{2}{*}{$\begin{array}{l}\text { Total } \\
\text { hardness, } \\
\mathrm{mg} \\
\mathrm{eq} / \mathrm{dm}^{3}\end{array}$} & \multirow{2}{*}{$\begin{array}{l}\text { Alkalinity, } \\
\text { mg-eq } / \mathrm{dm}^{3}\end{array}$} \\
\hline & & $\begin{array}{l}\mathrm{Na}^{+}+ \\
\mathrm{K}^{+}\end{array}$ & $\mathrm{SO}_{4}^{2-}$ & $\mathrm{Cl}^{-}$ & $\mathrm{NO}_{3}$ & $\begin{array}{l}\mathrm{SiO}_{2}{ }^{+}+ \\
\mathrm{SiO}_{3}{ }^{2-}\end{array}$ & & & \\
\hline $\begin{array}{l}\text { Abalak } \\
\text { village }\end{array}$ & 172 & 36.1 & 40.5 & 17 & 1.8 & 4.7 & 244 & 2.8 & 2.7 \\
\hline $\begin{array}{l}\text { Bekerevo } \\
\text { village }\end{array}$ & 165 & 37.1 & 41.5 & 19 & 2.4 & 8.7 & 344 & 3. 0 & 2.7 \\
\hline $\begin{array}{l}\text { Sumkino } \\
\text { settlement }\end{array}$ & 180 & 35.1 & 42.5 & 20 & 2.7 & 9.7 & 360 & 3.5 & 2.7 \\
\hline
\end{tabular}

High indicators of solid residue show a high content of salts. At the same time. the total hardness is quite low. which proves the possibility of water usage for water supply and steam production in the heat and power industry of Tobolsk and its district.

\section{Conclusion}

The results of the experiment have shown that the underground and surface water of the Irtysh. Tobol are qualitative natural sources of water supply. The waters of the Irtysh river contain substances of mineral and organic origin. as well as microorganisms. The mineral composition of water is determined mainly by the features of the hydrological layers through which the river flows. The organic composition is formed mainly by compounds that are washed out of the soil by the reservoir itself as the result of biological processes. Mineral and especially organic substances are brought to the Irtysh by waste water of populated areas and industrial enterprises. The Irtysh water is fresh. belongs to the hydrocarbonate class. For water supply and steam production in the heat and power industry of Tobolsk region. the source water is purified with the help of ionic desalination. Water pretreatment for desalting is carried out using mechanical filters [8].

In the experimental work on the research of the underground and surface water quality. students of chemical-engineering department were involved. The effectiveness of the experimental work was reflected in the thesis research and term projects on the request of the industrial enterprise.

\section{References}

1. A.I.Petrov. Current problems of the natural environment changing (Moscow, 2005) [in Russian]

2. Yu.V. Alekseev. Heavy metals in soil and plants (Moscow, 2014) [in Russian]

3. Ya.M.Amosova. Soil protection from chemical pollution (Moscow, 2015) [in Russian]

4. G.P. Bespamyatnov. The maximum permissible concentrations of chemicals in the environment (Saint Petersburg, 2014) [in Russian]

5. V.D. Shantarin. Health Safety and Industrial Safety (Tyumen, 2014) [in Russian] 
6. I.I. Borodavchenko. Integrated use and protection of water resources (Moscow, 2016) [in Russian]

7. G.I. Egorova. Current problems of chemistry. chemical technology, ecology (Tyumen, 2011) [in Russian]

8. D.S. Luzhkovoy. O.Yu. Romashova. A.A. Tubolev. Yu.V. Kobenko and E.S. Riabova. MATEC Web Conf. 92. 01054 (2017) 